\title{
Career Guidance at Kindergarten, Is It Neccessary?
}

\author{
Dede Rahmat Hidayat, Wahyu Ningrum \\ Department Guidance and Counseling, Faculty of Education, Universitas Negeri Jakarta, Indonesia \\ Corresponding e-mail : dederhidayat@unj.ac.id
}

\begin{abstract}
Career basically is an achievement to adulthood, because it will be related to work activities For achieve the right career should be prepared in early, starting from early education until higher education . Kindergarten to be starting point for childs early start to learn, and should be early prepapare for career development in adulthood. Career guidance program at kindergarten is directed to the identification and development of student potencies. At the time in kindergarten potencies of the child is known to then be developed through learning. Ideally this program drafted and implemented by Guidance and Counseling teachers, but not generally available in kindergarten, so it can be done by classroom teachers who have an adequate understanding of the potency identification and development of students. There are five main elements to be considered in career development programs in kindergarten, the development of techniques to identify potencies asessmen, career guidance subject, methods of career guidance, media will be used in career guidance and evaluation techniques to be used in career guidance.
\end{abstract}

Keywords : potencies of students, career guidance, program of guidance in kindergarten

\section{INTRODUCTION}

Learning in kindergarten (TK) has a major contribution to the development of early childhood education to prepare for the formal education in elementary school. Variety of learning activities that are developedsuch a game or other fun activity is an effort to optimizing the intellectual potential of early childhood. Bloom (in Wiyani, 2014) said that in early childhood intellectual development occurs very rapidly in the early years of early development of their life, that's why this period is called the golden age. About $50 \%$ of adult's intelligence happens when children aged 4 years. The next $30 \%$ increase occurred at the age of 8 years, and the remaining $20 \%$ by the middle or end of the second decade. This means that developments in the age of 0-4 years as big as the developments at the age of 418 years. That was what made all the activity at an early age can not be taken lightly, because a lot of things that can be used as a medium of learning for children and support the potential of his brain.

Learning by playing is one of the important principles in kindergarten education. Hurlock (1980) explains that the playing is an activity that is serious in childhood and is a means for improvisation and combination, this is the first of regulatory system through controls on culture the child's nature is ruled by childish impulse. Thus the play is the child's activity in order to learn not only to understand the object being played but also learn about the regulations that apply in the environment.

\section{CAREER GUIDANCE FOR EARLY CHILDREN}

Career guidance has not become a popular issue in the levels of early childhood education, particularly kindergarten. For a whiile introduction and career planning is not yet a sustainable program for all levels of education, especially at the level of preschool and elementary school. Generally, the students are invited to think seriously about career at the high school level (or an equivalent). At the junior high level students are encouraged to think about career when choosing between senior high school or vocational high school level. Commonly they are confused to choose between these two levels due to not understand what their ideals. After graduating high school, confusion to determine what is in demand majors in college is continues. Even, after graduating from college they are working in the field that much different from when their college majors. This phenomenon makes a lot of students who simply choose, just look at the job prospects are better in the future or by a short analysis to deciding choose the university departments. They often do not realize that the 
selection of work that will be their career also need to consider the characteristics of a job tailored to their talents, interests, personality and even posture.

The preparation of a person's career is not an instant process, but requires considerable preparation and in a long time. Magnuson \& Starr (2000) states that career development is a long process that affects and is affected by the role of a person's life, background and a lot of events going on. According to their career development in life coincide with the cumulative effect of awareness and exploration that leads to awareness of one's career. Thus a child who has not had a career awareness needs to be nurtured to exploring variety of career that have a variety of information to career decision at the future.

Ideally, career guidance is a continuous program in all of education'slevel as it has done like in the states of America (Sharf, 1992). Programs they design guidance set starting from the gardens of childhood through grade twelve with an emphasis on optimizing the development of personal / social, learning, and career while still based on developmental tasks that need to be achieved at any age growth.

Many consider children at kindergarten age is still too young to talk about careers. It is not visible from the inclusion of career development in the kindergarten curriculum as one of the developments that need to be achieved through specific competencies. Learning in kindergarten conducted thematically, namely by taking a particular theme each week to achieve the expected competencies in every aspect of development.

Ideally, the stimulus has given to the child should not only to learn about independence or prepare them toward elementary school but also introduces a career as a goal to be achieved in the future somebody. Careers need to be introduced early on to children for the following reasons: The earlier they understand the various career options it will be easier for them to choose a career field that will be occupied in the future by adjusting talents and interests as well as the suitability of the personal characteristics on the career field Lee (2012). When children have a career awareness, they will have a fantasy about a particular job, make a tentative decision and choose a job based on a realistic assessment of himself and his environment. A children about the job will bring her seek more information about the job. The more he grows up he will learn competencies themselves with the work she liked, and eventually will form a decision whether he fits the job qualifications.
Information on jobs and careers and to develop habits of the world of work will make them have a broader picture of the world. (Duffy, 1989 in Harkins, 2001). A picture of a career at an early age will lead them to discover more about the various career fields (Araujo and Taviera, 2005). It is clear that the discussion of a career must begin when the child is still a very young age. Thus a child has a relatively long time to prepare and consider a variety of things that will support them in certain career fields.

The provision of career information in early childhood has a great impact on children's cognitive development, not just in the career field, but can reach other aspects of a child's life. A study conducted by Lee (2012) to 1044 students of kindergarten age 5-6 years showed that children can identify tasks based on the employment of their fathers and mothers. The boy showed the selection of work by occupation dominated by men, such as architects, engineers, firefighters and police. While girls prefer non-traditional jobs, such as teachers, artists, celebrities and beauty consultant. The study also shows that the selection of work in early childhood influenced by the identification of the role of parents and their teachers. This becomes an important discovery that the surrounding environment, especially teachers and parents become a figure which can influence the career development of young children. Not only that, it was the children can identify tasks based on gender differences were observed from the people around him. This gender identification if directed positively by teachers or parents can give a better understanding, contributing to children. They can learn that the choosing of work are often not limited by gender differences, but based on certain specifications that can be learned and developed on early.

Career need to be introduced early on to children so that they have an idea of the jobs that exist around them. The earlier they understand career options it will be easier for them to choose a career field that will be occupied in the future by adjusting talents and interests as well as the suitability of the personal characteristics on the career field. (Reed, 2008 in Lee, 2012). When children have a career awareness, they will have a fantasy about a particular job, make a tentative decision and choose a job based on a realistic assessment of himself and his environment. A children about the job will bring her seek more information about the job. The more he grows up he will learn competencies themselves with the work 
she liked, and eventually will form a decision whether he fits the job qualifications.

A variety of information about jobs and careers and develop habits in the world of work will make them have a broader picture of the world (Duffy, 2001). A picture of a career at an early age will lead them to discover more about the various career fields (Hartung et al., 2005; Porfeli \& Vondracek, 2007; Roe, 1957; Roe \& Lunneborg, 1984; Skorikov \& Vondracek, 2007; Super, 1957, 1980, 1990; Taveira, 1999; Watson \& McMahon, 2005 in Araujo and Taviera, 2005). It is clear that the discussion of a career must begin when the child is still a very young age. Thus a child has a relatively long time to prepare and consider a variety of things that will support them in certain career fields.

Providing career information in early childhood has a huge impact on children's cognitive development, not just in the career field, but can reach other aspects of a child's life. Berdasdarkan research conducted by Lee (2012) to 1044 students of kindergarten age 5-6 years showed that children can identify tasks based on the employment of their fathers and mothers. The boy showed the selection of work by occupation dominated by men, such as architects, engineers, firefighters and police. While girls prefer non-traditional jobs, such as teachers, artists, celebrities and beauty consultant. The study also shows that the selection of work in early childhood influenced by the identification of the role of parents and their teachers. This becomes an important discovery that the surrounding environment, especially teachers and parents become a figure which can influence the career development of young children. Not only that, it was the children can identify tasks based on gender differences were observed from the people around him. This gender identification if directed positively by teachers or parents can give a better understanding, contributing to children. They can learn that the selection of work are often not limited by gender differences, but based on certain specifications that can be learned and developed early on. The above research shows that those who are around early childhood have a major role in providing career information. This is similar to Drier (2000) which states that a lot of people are influenced by a mentor, career interests and work behavior is taught and explored by a certain figure. Drier further revealed that the career and life planning activity within kehidupan.yang not happen at one time, but an activity that is planned for a long time and in a structured form. Therefore, adults as mentors who accompany the development of children needs to provide comprehensive guidance to deliver career education be based on the initial capital planning careers in life.

If early child get career guidance so they can have a variety of job preferences so it can do more exploration of the various types of work. They will be easier to make decisions regarding her options for the future. Not only that, they also understand the essence of the cultural importance of the work to be developed as personalities themselves as self pernyiapan efforts towards the world of work is increasingly competitive. Thus, career guidance at an early age, particularly at the kindergarten has a considerable influence on the development of an individual's career horizons

\section{THE CONCEPT OF CAREER GUIDANCE IN KINDERGARTEN}

The introducing about career at some kindergartens included in the theme of learning or arranged integrated on other themes to disclose the types of jobs that exist in the environment around children. While in some kindergartens, the formation of the theme to the topics raised intentionally work to focus the attention of children against various types of career options in the future. It has been a good step performed by the teacher and also the school in the process of career recognition to children. But need to be improved, so that the theme of the work that is raised not only be information for children but can build career awareness that encourages career exploration process in the future.

Schultheiss (2005) states that a program that introduces young students about the world of work will help them understand the connection between what they learn in school and what to expect in the world of work is essential to promote lifelong learning, educational environment that is productive and success in the future from school to work. Sharf (1992) acknowledges that career guidance is a vital dimension of human development, an essential element in basic education, and a means of promoting equal opportunity. Based on the above opinion, it can be said that career guidance is one of the important things that can support human development. Career guidance program that is designed properly it will provide insight on the student / $i$ of the correlation between education and the world of work and promote the principle of equality in choosing a particular career field.

Career guidance at the kindergarten level pursued as an aid to early childhood to get to know and understand her, to know the world of work, developing their future in accordance with the form 
of life that is expected in simple patterns that are tailored to the characteristics of children in an effort to build career awareness for students in kindergarten.

Job readiness evolving all the time and it needs to be developed since early in children. Readiness need to be developed through career education, as for the goal ( Schultheiss, \& Palladino, 2001) are : Gather information, Children have been able to understand the qualifications of a job. Teachers can be start with something familiar, such as the ability to drive. Children can remember it when they saw the vehicles on the streets, they can understand that the job of being the driver requires them to always be behind the wheel. They also can speculate any jobs that require physical strength.Children can also learn about the condition of a job. They will be aware of the differences in the workplace from a job, whether the work should be done inside or outside the room. They can also connect a job with the clothes to be worn. Furthermore, they can understand that a job is more fun than other jobs. The information provided should be tailored to the child's ability. Thus, the role of teacher and supporter of information media has become so important in the implementation of career guidance in the age of the children.

Self-awareness developing; Children will immediately grasp the talent and the joy that is owned by his friends. Questions such as, "You're happy to do what? What is your talent? "Will help children to understand themselves and build up talks on a variation of a work based on the things he liked. For example, a child who loves plants but do not want to be farmers to talk that he could be the one that regulates the sale of plants or other work that has a relationship with kesuakaannya on something.

Establish habits and a positive attitude; Children can learn that there are linkages between the various things he had learned in school with the things the world needs work. As he is not expected to come late to school because some jobs require punctuality. For example, children coming late to school the teacher gave us a card marker "delay". Next, the teacher will invite children to come to discuss the importance of timely hubungnanya with work habits in the industry.

Exploring the issue of equal; Teachers can help children to become someone who is open-minded to invite children to see and understand the differences within the community. For example, teachers encourage children to understand that either men or women can do great things.
Increasing competence; Teachers can improve the competence of children not only in terms of reading, writing and arithmetic. But it can also have the ability to teach students soft skills, such as collaboration, communicate well and use the computer as a form of control technology

(Secretary; s Commission, 1991)

Referring to the explanation above, the purpose of career guidance not only children know and understand various jobs, but also being able to have good social skills. A child is expected to have an understanding that to be successful in the job, a person needs to have good cooperation, communication skills, time, responsibility is, honest and various other positive attitude. The name is a symbol of work, but how the child can adopt good values and attitudes that are inherent in him something important.

Career guidance at the kindergarten level in many states have been included in the curriculum of integrated guidance and counseling to 12 th grade.

\section{CONCLUSION AND DISCUSSION}

Childhood is the golden period of brain development, so the children need to get more a variety of stimuli on career information in order to develop the cognitive potential that can leads to career awareness.Career information owned early childhood will build awareness of students to further explore their own potential and develop competencies that match the career field of interest.The need for the role of Guidance and Counseling teachers, classroom teachers, parents and the parties involved in early childhood education to provide proper career guidance so that students kindergarten can find their potential and continue to develop the potencies activities that supported.

\section{ACKNOWLEDGEMENTS}

This paper can't be accomplished without supporting all colleagues in Department guidance and counseling Faculty of education State University of Jakarta, so we say Thank you to you all, also for dean of faculty of education Dr. Sofia Hartati, M.Si and Prof. Dr. Djaali, as rector State University of Jakarta who has given us an opportunity to present this paper and all person who can mentioned one by one. 


\section{REFERENCES}

Araújo, A. M. Taveira, Maria d C. (2009). Study of career development in children from a developmental-contextual perspective. European Journal of Education and Psychology Vol. 2, No 1 (Páge. 49-67)

Asmani, Jamal Ma'mur. (2009). Manajemen Strategis Pendidikan Anak Usia Dini.Jogjakarta : Diva Press

Blustein, D. L. (1997). A Context-Rich Perspective of Career Exploration Across the Life Roles. The Career Development Quarterly. Vol 45,3, pg. 260

Cerrito, J. A. (2013). Disertasi : An Examination Of Career Guidance Programming On Elementary School Students' Vocational Development. The Pennsylvania State University.

Drier, H. N.(2000) Special Issue Introducing: Career and Life Planning Key Feature Within Comprehensive Guidance Program. Journal of Career Development; Winter (27).2 p.73

Gunawan, Dedi.(2012). Model Bimbingan Pengembangan Karir. Jurnal Penelitian PendidikanVol. 13 No. 2 Oktober

Hurlock, E. B. (1978). Perkembangan Anak.Jakarta:Erlangga

Hurlock, E B. (1980). Psikologi Perkembangan: Suatu Pendekatan Sepanjang Rentang Kehidupan. Jakarta: Erlangga

Kasim, Anwar. (2001). Bimbingan Karir di Sekolah dan Perguruan Tinggi. Jakarta: Universitas Negeri Jakarta

Lee, H-C. (2012). What Do You Want To Do When You Grow Up?'Occupational Aspirations Of Taiwanese Preschool Children. Social Behaviour and Personality; 40,1; ProQuest Sociology pg. 115

Magnuson, Cn S. Starr, Marion F. (2000). How Early Is Too Early to Begin Life Career Planning? The Importance of The Elementary School Years.Journal of Career Development. Winter. (27) 2. P. 89

Mashar, Riana. (2011). Emosi Anak Usia Dini dan Strategi Pengembangannya.Jakarta : Prenada Media Group.

Nazli, Serap. (2013). Career Development of Upper Primary School Students in Turkey. Australian. Journal of Guidance and Counselling. Vol 24 Issue 1 pp 49-61
Kompas. (2010). DO Akibat salah jurusan. Diakses November 18, 2015, dari http://edukasi.kompas.com/read/2010/11/10/0 5360848/do.akibat.salah.jurusan

Santrock, J. W. (2007). Perkembangan Anak. Jakarta : Erlangga.

Schultheiss, D. E. Palladino (2005). Elementary Career Intervention Programs:Social Action Initiatives. Journal of Career Development, Vol 31. No.3, Spring 2005

Sharf, R.S.(1992). Applying Career Development Theory To Counseling. California : Brooks/Cole Publishing Company

Suherman, Uman. (2013). Bimbingan dan Konseling Karir: Sepanjang Rentang Kehidupan. Bandung : Rizqi Press

Sujiono, Yuliani Nurani. (2013). Konsep Dasar Pendidikan Anak Usia Dini.Jakarta : Indeks

Sugiyono. (2011). Metode Penelitian Pendidikan Pendekatan Kuantitatif, Kualitatif, dan $R \& D$. Bandung : Alfabeta.

Syaodih, Ernawulan. Agustin, Mubiar. (2011). Bimbingan dan Konseling untuk Anak Usia Dini. Jakarta: Universitas Terbuka

Tohirin. (2013). Bimbingan dan Konseling di Sekolah dan Madrasah (Berbasis integrasi).Jakarta: PT Raja Grafindo Persada

Trice, Ashton D, et al. (1995) The Origins Of Children's Career Aspiration:IV.Testing Hypotheses From Our Theories.The Career Development Quarterly, 06, (43), Issue 4

Walgito, Bimo. (2005).Bimbingan dan Konseling (Studi \& Karir). Yogyakarta: Andi

Wiyani, Novan Ardy. (2014). Psikologi Perkembangan Anak Usia Dini. Yogyakarta:Gaya Media.

Yusuf LN, Syamsu, Nurihsan, Juntika. (2006). Landasan Bimbingan dan Konseling. Bandung : PT Remaja Rosdakarya

Watson, Mark. McMahon, Mary. (2005). Children's Career Development: A Research Review From A Learning Perspective. Journal of Vocational 67. 119- 132

Wiyani, Novan Ardy. (2015). Manajemen PAUD Bermutu. Yogyakarta: Gaya Media

Zunker, V. (2006) Career Counseling A Holistic Approach. Thomson Brooks/Cole: USA 